\title{
ADVANCES IN SHEET METAL FORMING TECHNOLOGIES
}

\begin{abstract}
In the article the changes associated with construction of machines used in die and die-less sheet metal forming have been presented. The selected future directions of development in new technologies and machines for sheet metal forming taking into account modern blank holding systems in the process of deep drawing have been indicated. Also the tendencies in introduction of new technologies and modernization of presently used technologies in order to increase productivity have been discussed.
\end{abstract}

Keywords: blankholder, blankholder system, deep drawing, sheet metal forming

\section{Introduction}

The development of power transmission systems of modern machines results in replacement of mechanical drives by hydrostatic, electrical and hybrid drives. The control of technological machines for metal forming is based on computer numerical control (CNC) systems and programmable logic controllers (PLC) as well as digital linear actuators. Mechanical transport mechanisms are replaced by robots and manipulators with higher adaptivity. Together with development of hydraulic and pneumatic drives, servo drives and digital linear drives it is possible to optimize the operating space of machines and to decrease the material consumption index. The most important characteristics of CNC machines used in sheet metal forming compared to the conventional machines are:

- automatic control systems feedback with control computer,

- many axes numerically controlled,

- application of automatic tool changer systems and 3-axis automatic modular transport systems,

- automatic diagnostic systems of collision and errors of primary control program,

- application of servo drives and precise toothed bars allowing to minimize clearances. 
Introducing into the market new constructional solutions of machines is connected with analysis of raising expectation of dimensional accuracy of products, processing speed, forming forces as well as static and dynamic rigidity [1]. Analysing the machine market over last few years it can be observed, that producers are concentrated on elastic adaptation of machines for industrial consumer needs [2].

\section{Deep drawing}

The development of sheet metal forming presses is connected with growing requirements of automotive industry and is focused on improvement of material flow and modernization of press driver. Increasing of material flow rat is realized by connection of press lines by using robots and 3-axis transfer machines with modular transport systems [3]. Presently used autogenous press lines are composed with autonomous systems of material supply, manipulation and transport of finished products [4]. The CNC controlling in hydraulically driver forming presses enables regulation of forming force and speed of press ram in the whole range of slide motion. The servo drive of crank presses allows for selection of drawing characteristics with codominant lower energy-consumption compared to the classical drives.

The introducing into the market servomotors coupled with programmable PLC controllers by SEYI enables modification of stamping process characteristics and it is possible to set up low rotational speed of crankshaft. The example of usage direct servo drive press SD series is pressing with programmable pulsating motion that reduces undesirable residual stresses in a drawpiece [5, 6]. The innovative compact design of the press frame is combined with its own motor design - specially developed, low speed servomotor with high torque and low energy consumption. Combined with an easy-to-operate, free programmable control system, it is possible to achieve dramatically reduced power consumption, improve productivity and extend tool life by 5-10 times.

Progress in sheet metal forming technology is also connected with development of new techniques and machines for sheet metal cutting [7]. Modernization of sheet-metal forming presses is connected not only with development of traditional stamping methods but also there is the extensive growth of new machines using a multi-segmented flat and tapered blankholders [8], pulsatory and elastic blankholders [9], intelligent multi input multi output (MIMO) systems with numerically controlled blankholder force (BHF) [10, 11]. 


\section{Progress in blankholder systems}

In the pulsating blankholder system the blankholder is subjected to a vibratory (pulsating) force. The metal flowing into the bottom die is subjected to intermittent pressure at a frequency of up to $20 \mathrm{~Hz}$. The material flow much better under the blankholder without the disadvantages of an essential low hold-down force. Increase of pulsation amplitude of the blank holder leads to decrease of frictional resistance and has a decisive effect on drawpiece quality [12]. Some researches $[13,14]$ concluded that the increase of the frequency of the vibration leads to increase in the drawability and also results in a general decrease in thinning in comparison to the constant BHF. A pulsatory blankholder scheme could lead to reduction of the friction forces between the blankholder and blank, without increasing the danger of wrinkling and rapture [15]. The newest tendencies to minimize the punch force and increase in limiting draw ratios affected the development of friction-actuated blank-holding technique [16] and elastic (pliable) blankholders [17]. Blank holding is induced by applying a pressure on the upper surface of the elastic ring plate, which upon deflection would conform to the flange surface [12]. Application of elastically deformable thin plate instead of classical rigid blankholder aims at enhancing more uniform contact conditions nearly all over the flange zone in contrast to the contact at the outer rim of the flange which is dominant in the case of the conventional rigid blankholder. Present effort is made to develop effective optimization techniques and devices to control process parameters and optimize the blankholder schemes. Based on the punchless deep drawing process [18] a new eight segments flat blankholder device was proposed [19]. This device is made by fitting four flat small wedges in the gaps between the four flat drawing segments. In the case of forming thin sheets, a crack was observed due to the localized intensive shear deformation at the boundaries between the drawing segments and the wedges. To eliminate this defect a friction aided deep drawing process using tapered blankholder divided into four segments was proposed [20]. The blankholder is made by cutting a tapered steel blankholder into eight segments. It consists of a stationary base and eight tapered drawing segments that have similar planes of $5^{\circ}$ taper angle (Fig. 1c). The drawing segments can slide in radial direction under a constant speed over the tapered surfaces of the stationary base. In the first drawing step, deformation starts when four facing segments move radially inward to the die opening in the A-direction as shown in Fig. 1a. The other four segments in the B-direction move in the reverse direction, i.e. downward and radial outward opposite to the drawing direction as shown in Fig. 1b. In the A-direction the blank sheet and the die are lifted up (Fig. 1b), while in the B-direction there is no contact between the sheet and segments (Fig. 1c). 

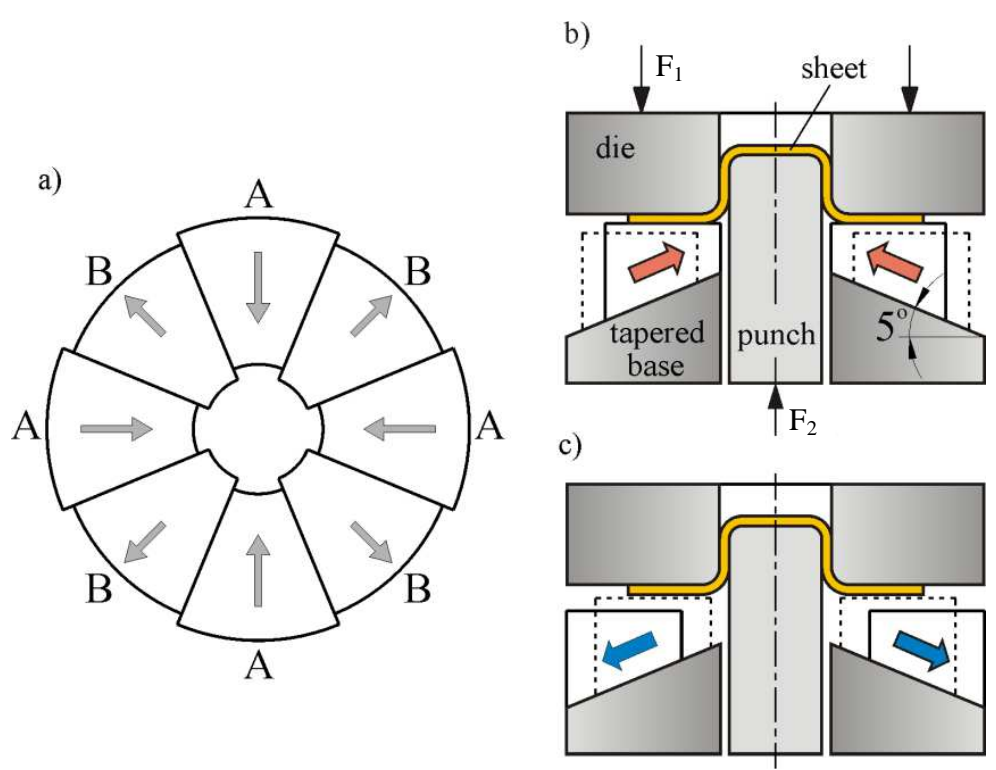

Fig. 1. Schematic of eight segments tapered blankholder (a) and schematic of die in motion $(b, c)$

The flexible manufacturing system using multi-point forming (MPF) technology is an advanced digital tooling system for the automatic fabrication of 3D surface parts [21]. The main characteristic of the deformation method is given by the active surface discrete design of the forming elements which are composed of a number of pins, vertically aligned, according with the geometry of the part [22]. The surface tooling in reconfigurable multipoint forming (RMF) is based on the concept of a die continuous surface discrete approximation (Fig. 2a). Usage of multi-point dies (Fig. 2b) mounted on special multipoint press machine (Fig. 2c) allows to obtain drawpieces with higher shape precision and under the decreased forming force, compared to traditional deep drawing.

Based on the MPF methodology, an innovative dieless tooling (DT) and jigless tooling (JT) system is being developed. The DT/JT system integrates the technology of MPF with the technology of computer-aided and computercontrolled manufacturing.

Overcoming mass production problems following try-out, new press technologies continuously emerge as new techniques and ideas in sheet metal forming are considered in press design. Controlling the flow of sheet metal via controllable multi-cylinder blankholder actuators reduces die-try out time by cutting down on die work [23-25]. The application of multi-input multi-output (MIMO) stamping process controller especially in case of forming complex-geometry parts allows to apply the non-uniform BHF in different regions of the drawpiece $[23,26]$. 
a)

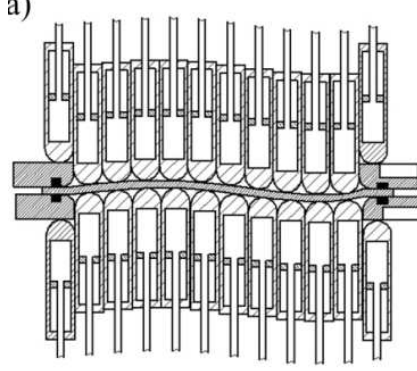

b)

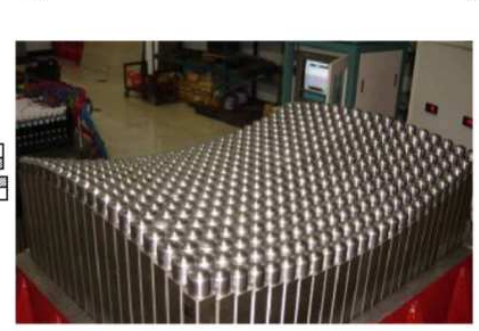

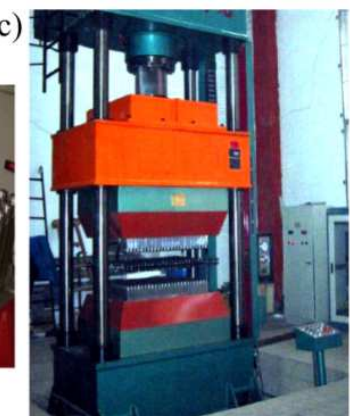

Fig. 2. Reconfigurable surface tooling (a), multi-punch stamping die (b) and multipoint forming press machine YAM8-315 (c), prepared on the basis of [21, 23]

The deep drawing processes usually were done in the double-acting presses (most often used) with two rams or in the single-acting presses with a cushion system in the press table. In some single-acting presses, hydraulic cylinders are installed at the four corner points of the press table. Each cylinder has its own proportional or servo valve so that specific BHF can be run over the stroke for each cylinder. The BHF is transmitted from the cushion plate to the blankholder by several cushion pins. Numerically controlled height-adjustable cushion pins in hydromechanical multipoint cushion system have been recently developed [27]. Each cushion pin has its own load cell to monitor the BHFs, which are introduced to the blankholder. In the flexible die blankholder system the blankholder is made from a nylon-based thermoplastic material and designed with pyramid-shaped steel inserts (Fig. 3). The BHFs are introduced into the pyramidshaped steel inserts (top down), so there is a clear correspondence between the BHF and the pressure-influenced base area of the pyramid. Between the stiff steel inserts, the flexible plastic material acts like elastic links.
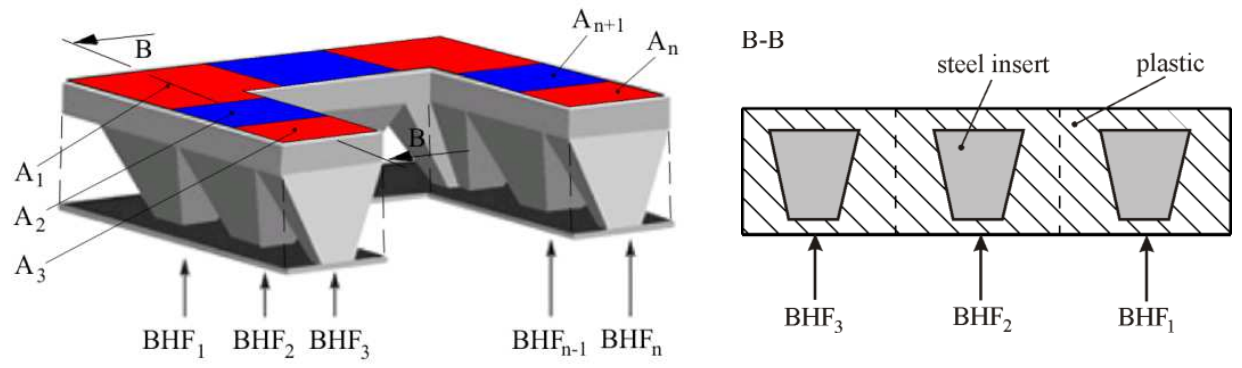

Fig. 3. Multi-point blankholder, where: $A_{1}-A_{3}-$ flat surfaces, BHF (1- n) blankholder forces 


\section{Development of other innovative processes}

Development of innovative sheet metal forming technologies in last years determines progress in control systems and construction of presses and tools. Considerable growth of forming techniques may be noticed in hydroforming, electromagnetic metal forming, sheet metal forming with elastic tools, cavity forming processes (pneumatic bulging) of superplastic sheet metal forming, laser forming and laser assisted forming, magnetic-pulse forming, shot peen forming and methods of incremental forming.

Sheet hydroforming (SHF) is a technology that uses hydraulic fluid taken to very high pressure as an essential tool in transforming sheet metal and tubes fitted to a specially designed die. Sheet hydroforming technology is classified into SHF with a punch (SHF-P) and SHF with a die (SHF-D) depending on whether a punch or a die will be used to form the blank. In hydroforming processes there is a possibility to make complex metal parts, with special curves, even with unusual shapes and a possibility to reduce the number of components in a product, resulting in economic savings and increased performance. Nowadays, SHF is widely accepted for the industrial produced components characterized by fine surface quality, accurate dimensions, high drawing ratios, and complex shapes [28]. Multi-stage SHF increases the formability of structural parts [29]. SHF technologies are now commonly used in automotive industries to produce fuel tanks and tubular parts for exhaust systems. The last technological development in hydroforming techniques consists of combining tube bending, tube hydroforming and tube welding in a flexible manner using reconfigurable machine tool equipments easily adaptable to various production batches [30]. Flexforming is a type of hydroforming process in which the sheet metal is forced to take the shape of a rigid die by the action of fluid pressure which acts through a rubber diaphragm (Fig. 4). In this process there is only a single rigid die providing low die costs, the easy modification of the dies after changes leading to fast tryouts, and finally high quality parts. The flexforming process needs

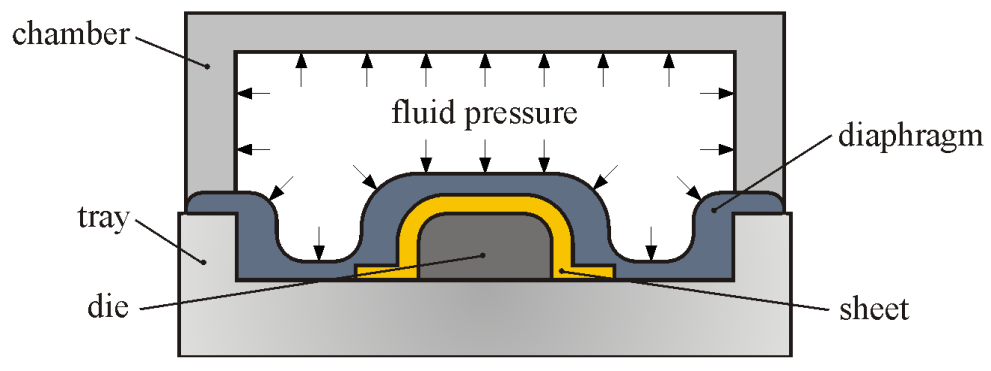

Fig. 4. The schematic representation of the flexforming process 
special presses to stand for high pressures up to $80 \mathrm{MPa}$ in the pressure chamber. Sheet metal forming with elastic tools is commonly used in aircraft industry, especially for forming stainless steels nickel alloys sheets.

In order to reduce setup time of production and production cost in small batch production the incremental forming (IF) may be used. IF is dieless forming process and has demonstrated its great potential to form complex threedimensional parts with using a relatively simple and low cost tools. The theory is that delaminating a complex surface 3D digital model along the contour line, and forming a series of section 2D data, the doing plastic forming from the top to the bottom level by level and part by part according to the section 2D data. Negative dieless incremental forming, also known as single point incremental forming (SPIF) is the earliest form of incremental forming. Positive die-less incremental forming is also referred to as two point incremental sheet forming (TPIF). The main advantages of incremental forming are high process flexibility, relatively low hardware costs and enhanced formability (Fig. 5) [31, 32]. A greater deformation of a sheet metal can be achieved in the incremental forming compared to conventional forming [33]. The forming limit curve, which depicts the formability in the major and minor strain space, is expressed as a straight line with a negative slope. It is noted [33] that formability is the greatest under plane-strain stretching, during which the minor strain is zero. Potential application areas of IF include aerospace industry, biomedical applications and prototyping in the automotive industry.

Fig. 5. Forming limit curve in IF compared to conventional forming limit curve: material with good formability (aluminium)

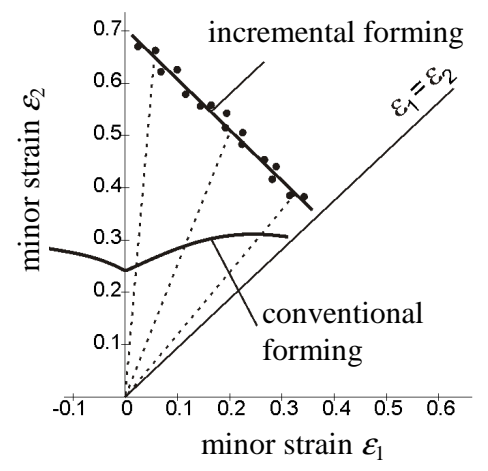

One variant of SPIF method is forming by water jet [34] as a forming tool, where the metallic contact between forming tools and the sheet was eliminated. This new variant such as the water jet system is a force controlled operation whereas the numerically controlled tool system used in SPIF is a displacement controlled system. Water jet forming is a special variant of incremental forming, where a high-pressure water jet has replaced the common steel punch. In water jet forming process a can is placed inside a mould (die) and over a set of rotating 
nozzles - typically 2 (Fig. 6). The rotating nozzles produce columnated (straight) high pressure water jets that spray against the can wall and push the can wall outwards. At the same time the nozzles move vertically at a constant speed, so that the point of impact of the water jet travels over the can wall in a spiral trajectory [34]. Typical parameters of the water jet forming process are: nozzle rotation $5000 \mathrm{rpm}$, water pressure 100-350 bar.

To form hard deformable alloy sheets, especially magnesium and titanium alloys, a hot incremental forming (HIF) has been developed [35]. Possibility to realize IF in conventional $\mathrm{CNC}$ controlled machine causes that there is not observed a significant progress in production of specialized CNC machines for incremental forming. The exceptions are machines of AMINO Corp. series DLNC with movable table and with feeding speed up to $60 \mathrm{~m} / \mathrm{min}$ allowing to form e.g., aluminium alloy sheets with thickness $0.5-5 \mathrm{~mm}$ and stainless steel sheets with thickness up to $2 \mathrm{~mm}[6]$.

Fig. 6. Scheme of water jet forming process, prepared on the basis of [34]

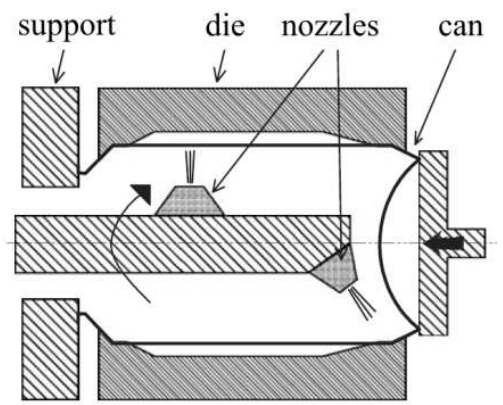

The electromagnetic forming process (EMF) is a highly dynamic process using pulsed magnetic fields to form metals with high electrical conductivity such as aluminium. In this process, deformation of the workpiece is driven by the interaction of a current generated in the workpiece with a magnetic field generated by a coil adjacent to it. Due to the process principle local workpiece velocities of more than $300 \mathrm{~m} / \mathrm{s}$ [36] are achievable within the EMF process, whereby a high contact force between the workpiece and the die occurs during the impact. The EMF technique is particularly attractive for the aerospace and automotive industries due to several potential advantages over conventional forming methods: low-cost single-side tooling, high speed (typical EMF current pulse rise times are on the order of $20 \mu$ s and after electromagnetic launch deformation may persist for a time on the order of milliseconds) and precise process control [37]. Compared with other sheet metal forming techniques, EMF offers several advantages [38]. However, there are also a number of limitations [38]: 
- only relatively thin-walled workpieces can be electromagnetically formed,

- EMF does not lend itself to processes such as deep drawing where significant material must be drawn in over the edges of the die with the aid of lubricants,

- only highly conductive workpieces or workpieces with highly conductive driver plates can be formed using this method.

Typical system for EMF process has been shown in Fig. 7.

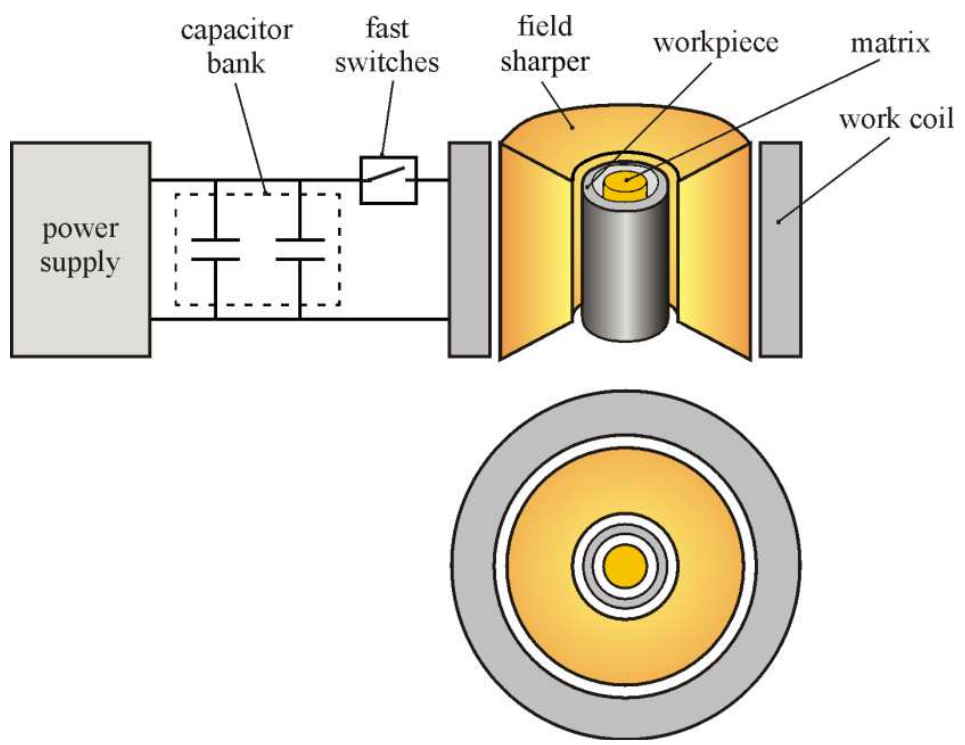

Fig. 7. EMF system with field shaper for compressing cylindrical

\section{Conclusion}

The development of computer numerical control machines for metal forming is directed on improvement of part quality, increase of productivity with concomitant performed economical and environmental protection aspects. In the metal forming machines area the development progression in automatic tool change system and part manipulation is evident. The technological progress is connected with introducing into the market self-service machines and autonomic modular machine production lines. With the CNC machines for metal forming simultaneously the development of systems for simulation of metal forming processes based on computer modelling is observed. Modern metal forming machine tools must conform to the current level of automated production, therefore they are equipped in monitoring and diagnostic system. Control systems of 
metal forming parameters are equipped in intelligent functions enable to on-line processing. Two main progress directions should be taken into consideration at further development of sheet metal forming technology. Firstly, the costs of development and production of new machines for forming of complex shell parts are extremely high and should be reduced. Secondly, it is necessary to reduce the time for developing, designing and producing the dies for the production of parts.

\section{References}

[1] Honczarenko J.: Rozwój i automatyzacja obrabiarek skrawających, cz. II, Mechanik, 83 (2010), 90-94.

[2] Kosmol J.: Kierunki rozwoju obrabiarek. Reminiscencje z Salonu MACH-TOOL na ITM 2011, Mechanik, 84 (2011), 660-664.

[3] Plewiński A.: Kierunki rozwoju maszyn do obróbki plastycznej, Obróbka Plastyczna, 16 (2005), 21-28.

[4] Trzepieciński T.: Rosnące znaczenie obrabiarek CNC w procesach obróbki plastycznej blach, Mechanik, 85 (2012), CD1.

[5] Kosmol J.: Tajwan - lider w produkcji obrabiarek. cz. I, Mechanik, 85 (2012), 26-28.

[6] Materiały firmowe i reklamowe firm: AMINO, SEYI.

[7] Trzepieciński T.: Trendy rozwojowe maszyn i technik stosowanych w technologii cięcia blach, Inżynieria Maszyn, 17 (2012) (accepted for publication).

[8] Hassan M.A., Takakura N., Yamaguchi K.: Friction aided deep drawing using newly developed blank-holder divided into eight segments, Int. J. Machine Tools Manuf., 43 (2003), 637-646.

[9] Ali S., Hinduja S., Atkinson J., Bolt P., Werkhoven R.: The effect of ultra-low frequency pulsations on tearing during deep drawing of cylindrical cups, Int. J. Machine Tools Manuf., 48 (2008), 558-564.

[10] Lim Y., Venugopal R., Ulsoy A.G.: Multi-input multi-output (MIMO) modeling and control for stamping, J. Dyn. Syst. Meas. Contr., 132 (2010), 1-12.

[11] Drenger T., Pawlicki M.: Nowoczesne systemy docisku blachy w procesie tłoczenia, Obróbka Plastyczna, 22 (2011), 83-109.

[12] Wifi A., Mosallam A.: Some aspects of blank-holder force schemes in deep drawing process, J. Achievements Mat. Manuf. Eng., 24 (2007), 315-323.

[13] Mori T., Uchida Y.: Effect of vibration on the blank holder in cup drawing, Proc. of 21st Int. Machine Tool Design and Research Conf., 1990, 237-242.

[14] Wifi A.S., Abdelhamid A.: Finite element analysis of deep drawing using a vibrating blank holder, Advances in Material and Processing Technologies AMPT'07, University of Minho, Portugal 1997, 815-822.

[15] Siegert K., Ziegler M.: Pulsating blankholder force in the deep drawing processes, Annals CIRP, 46 (1997), 205-208.

[16] Thiruvarudchel van S., Lewis W.G.: Deep drawing with blank holder force approximately proportional to the punch force, ASME J. Eng. Ind., 112 (1990), 278285.

[17] Ragab M.S., Sommer H.: Deep drawing with elastic blankholder (in German), Bänder Bleche Rohre, 25 (1984), 225-258. 
[18] Hassan M.A., Takakura N., Yamaguchi K.: Friction aided deep drawing using polyurethane ring and metal punch. Part 1: experimental observations on the deep drawing of aluminum thin sheets and foils, Int. J. Machine Tools Manuf., 42 (2002), 625-631.

[19] Kadkhodayan M., Poursan R.: Finite element simulation of process and springback of friction aided deep drawing using tapered blank holder divided into eight segments, Int. J. Adv. Des. Manuf. Technol., 3 (2010), 1-10.

[20] Hassan M.A., Suenaga R., Takakura N., Yamaguchi K.: A novel process on friction aided deep drawing using tapered blank-holder divided into four segments, J. Mater. Proc. Technol., 159 (2005), 418-425.

[21] Pham D.T., Su S.Z., Li M.Z., Liu C.: Digital dieless tooling and jigless tooling technology for manufacturing 3D panels using multi-point forming methodology, Proc. of Innovative Production Machines and Systems Conf. (IPROMS), 2007, 6-11.

[22] Hardt D.E., Norfleet N.A., Valentin V.M., Parris A.: In-process control of strain in a stretch forming process, J. Mater. Proc. Technol., 123 (2001), 496-503.

[23] Lim Y.S., Venugopal R., Ulsoy A.G.: Multi-input multi-output modeling and control for stamping, J. Dyn. Syst. Meas. Contr., 132 (2010), 1-12.

[24] Wang L., Lee T.C.: Controlled strain path forming process with space variant blank holder force using RSM method, J. Mater. Proc. Technol., 167 (2005), 447-455.

[25] Xu S., Zhao K., Lanker T., Zhang J., Wang C.T.: On improving the accuracy of springback prediction and die compensation, SAE Paper No 2007-01-1687.

[26] Lim Y., Venugopal R., Ulsoy A.G.: Improved part quality in stamping using multiinput multi-output (MIMO) process control, Proc. of American Control Conf., St. Louis 2009, 5570-5575.

[27] Siegert K., Hohnhaus J., Wagner S.: Combination of hydraulic multipoint cushion system and segment-elastic blankholders, Proc. of International Congress \& Exposition, Session: Sheet Metal Stamping, Detroit 1998.

[28] Tseng H.C., Hung J.C., Hung C., Lee M.F.: Experimental and numerical analysis of titanium/aluminum clad metal sheets in sheet hydroforming, Int. J. Adv. Manuf. Technol., 54 (2011), 93-111.

[29] Chen W, Liu Z.J., Hou B., Du R.X.: Study on multi-stage sheet metal forming for automobile structure-pieces, J. Mater. Proc. Technol., 187-188 (2007), 113-117.

[30] Chinesta F., Cueto E.: Advances in material forming, Springer-Verlag, Paris 2007.

[31] Attanasio A., Ceretti E., Giardini C., Mazzoni L.: Asymmetric two points incremental forming: Improving surface quality and geometric accuracy by tool path optimization, J. Mater. Proc. Technol., 197 (2008), 59-67.

[32] Trzepieciński T., Kowalik M.: Rozwój metod jednopunktowego tłoczenia przyrostowego na obrabiarkach CNC, Mechanik, 85-1 (2012), CD1.

[33] Kim Y.H., Park J.J.: Effect of process parameters on formability in incremental forming of sheet metal, J. Mater. Proc. Technol., 130-131 (2002), 42-46.

[34] Emmens W.C.: Water jet forming of steel beverage cans, Int. J. Machine Tools Manuf., 46 (2006), 1243-1247.

[35] Fan G., Gao L., Hussain G., Wu Z.: Electric hot incremental forming: A novel technique, Int. J. Machine Tools Manuf., 48 (2008), 1688-1692. 
[36] Ungera J., Stiemerb M., Schwarzec M., Svendsena B., Blumb H., Reesec S.: Strategies for 3D simulation of electromagnetic forming processes, J. Mater. Proc. Technol., 199 (2010), 341-362.

[37] Thomas J.D., Seth M., Daehn G.S., Bradley J.R., Triantafyllidis N.: Forming limits for electromagnetically expanded aluminum alloy tubes: Theory and experiment, Acta Materialia, 55 (2007), 2863-2873.

[38] El-Azab A., Garnich M., Kapoor A.: Modeling of the electromagnetic forming of sheet metals: state-of-the-art and future needs, J. Mater. Proc. Technol., 142 (2004), 744-754.

\section{POSTĘPY W TECHNOLOGIACH KSZTAETOWANIA BLACH}

Streszczenie

W artykule przedstawiono zmiany zachodzące w budowie maszyn stosowanych w technologiach matrycowego i bezmatrycowego kształtowania blach. Wskazano wybrane kierunki rozwoju technologii i maszyn do kształtowania blach, uwzględniając nowoczesne systemy docisku blachy stosowane w tłocznikach. Przedstawiono także tendencje we wprowadzaniu nowych technologii oraz modernizacji obecnie stosowanych celem zwiększania produktywności.

Słowa kluczowe: dociskacz, system docisku, tłoczenie, obróbka blach

DOI: $10.7862 / \mathrm{rm} .2012 .12$ 